\title{
The Achievement of Student Developmental Task Based on Type of School
}

\author{
Tazkia Dini Azhara' ${ }^{1}$, Herman Nirwana ${ }^{2}$, Syahniar ${ }^{3}$ \\ ${ }^{123}$ Universitas Negeri Padang \\ *Corresponding author, e-mail: bayujakapratama@gmail.com
}

\begin{abstract}
The objective of study is to describe the achievement of student developmental task based on the type of schools that are Senior High School and Islamic Boarding School. This study used quantitative methods with comparative descriptive approach. The samples in this study were amounted 429 students that consisted of 219 students of Public Senior High School 3 Padang Panjang, and 210 students of Islamic Boarding School of Sumatra Thawalib Parabek, Bukittinggi. The samples were selected by using the Proposional Random Sampling technique.The instrument used was Instrument of the Achievement of Student Developmental Task (IKTPS), with reliability of 0.925 . In testing the differences between independent variable and dependent variable were analyzed by $t$-test. The findings of study showed there were differences of the achievement of student developmental task with different backgrounds between Senior High School and Islamic Boarding School, which is student in Senior High School have higher levels of their developmental task achievement than student in Islamic Boarding School.
\end{abstract}

Keywords: Student Developmental Task, Student of Senior High School and Islamic Boarding School.

How to Cite: Azhara, T.D., Nirwana, H., Syahniar, S. (2020). The Achievement Of Student Developmental Task Based On Type Of School. International Journal of Applied Counseling and Social Sciences. 2 (1): pp. 31-39. DOI: 10.24036/005346ijaccs

This is an open access article distributed under the Creative Commons 4.0 Attribution License, which permits unrestricted use, distribution, and reproduction in any medium, provided the original work is properly cited. @2020 by Author

\section{Introduction}

Education aims to explore the potential of students optimally, through the education can be realized qualified young generation, both in the academic, religious and social fields. In constitution No 20 of 2003 about National Education System in article 3 is: "for the development of students potential in the order become human beings who have faith and piety to an almighty god, noble, healthy, knowledgeable, creative, independent, and become a democratic and responsible citizen". From that quotation above implies that education makes a whole human being, that is, the dignity of human being (Harkat Martabat 
Manusia/HMM) realized completely through the development of five dimensions of humanity with activating pancadaya optimally (Prayitno, 1997).

School as one of the formal educational institution should organize a quality education for the development of student's abilities and pontential as a manifestation of student learning progress. Moreover, as an education institution, the school also teaches about values and norms that apply in the school and in addition to teach about various skills and knowledgement to the students (Wirawan, 2012).

Educational character in Madrasa or Public School is one of educational discourse that considered able to provide the answers of impasse in the education system. Correspondingly, education of character is also interpreted as an effort to present intelligence of thinking, appreciation in form of attitudes and practices in form of behavior that accord with the noble of values which become his identity, represent in interactions with his Lord, himself, society and environment. Madrasa is a more modern Islamic educational institution, which combines Islamic education and public school education within integrates religion and general knowledge, implements religious values in the daily life both in teaching and learning activities, extracurricular activities, and activities that directly related to e social communities (Riadi, 2016).

A student should fulfill his developmental task so that he will be happy in the future. In filling up the development tasks that have to be fulfilled by students, the environtment have a very important role in helping the students fulfill their developmental task. Students can get guidance and direction through the formal education such as at school. So, the guidance and direction has a positive impact on the development tasks of students and they can also fulfill their developmental tasks as they have to fulfill them during a certain period. "All of developmental task of the student's term focused on prevention childish attitudes and behavior patterns and also preparation to deal with adulthood" (Hurlock, 1980).

In the moment of student development tasks can be fulfilled, it hoped those students will be mature, and their positive potential develop optimally and become the human being who take responsibilities for their Lord, themselves, family, society and country. Whereas, when the developmental task obstructed or failed to execute, so the students would get the problems that would be experienced in the present or future (Sofyan, 2005)

In addition, the research (Ardi et al., 2012) presented that based on the analysis data results that have been discussed about achievement of social development tasks of students with the peer group, it can be concluded that achievement of social development tasks of students with the peer group in grade XI of Public Senior High School of 1 Padang regarding with the ability to carry out in social role according to the gender generally has been achieved, athough to the several students, it has not been achieved optimally.

The research about obedience of students with the rules in modern Islamic boarding school concluded that the rules are influenced by internal factors including emotional condition, self-awareness, responsibility, moral reasoning and self-control, as well as external factors including peer behavior, exemplary teacher, exemplary administrators of school organization, enforcing rules and punishments. Teachers who can enforce the rules consistently and administrators of school organization that are able to be an example of role model cansupport compliance of students with the rules, while teachers who are unjust in enforcing the rules and administrators of school organizations who are unable to obey the rules made students do violations of the rules.Students who show obedience to the rules are able to understand the values of obedience and discipline, so that they can control actions 
that against the rules. The most common types of violations committed by students are violations in the language section, followed by violations in the security section, the religious section and the student section (Rahmawati, 2015).

The results of research on student discipline at school and its implications in counseling guidance services are namely the implementation of student discipline in neatness, the implementation of student discipline in diligency, and the implementation of student discipline in study time control. Whereas, most of all, the implementation of student discipline in a quite good category is the implementation of student discipline in environmental cleanliness and the implementation of student discipline in behavior. The factors that support the implementation of student discipline in school on average are classified as good categories, they are oneself and peers, while as a quite good category are from the environment itself (Fiana et al., 2013).

Based on the background and results of previous studies, the researcher intends to conduct the study about the achievement of students' developmental task in terms of the type of school. The purpose of this study is to describe the achievement of students' development task based on the type of school, specifically in Senior High Schools and Islamic Boarding Schools.

\section{Method}

This research uses a quantitative method with a descriptive or comparative approach. The population taken for this study was amounted to 937 students that registered in the second semester from January-June 2019 in the academic year of 2018-2019. It is described in Table 1 as below:

Table 1. Data of Population and Samples

\begin{tabular}{ccc}
\hline Type of School & $\begin{array}{c}\text { Population of } \\
\text { Students }\end{array}$ & $\begin{array}{c}\text { Samples of } \\
\text { Students }\end{array}$ \\
\hline Senior High School & 515 & 219 \\
Islamic Boarding School & 422 & 210 \\
Total & 937 & 429 \\
\hline
\end{tabular}

Based on Table 1 above, the population was consisted of 515 students of Public Senior High School 3 Padang Panjang, and 422 students of Islamic Boarding School of Sumatra Thawalib Parabek, Bukittinggi. The samples were selected by using the Proposional Random Sampling technique, so the samples in this study were obtained 429 students that consisted of 219 students of Public Senior High School 3 Padang Panjang, and 210 students of Islamic Boarding School of Sumatra Thawalib Parabek, Bukittinggi. The instrument used in this study was Instrument of the Achievement of Student Developmental Task (IKTPS) with reliability of 0.925 . In testing the differences between independent variable and dependent variable were analyzed by t-test and assisted by program of Statiscal Product and Service Solution (SPSS) 20.0 version. 


\section{Results and Discussion}

In this study, the data include variable type of school $\left(X_{1}\right)$ and the achievement of student developmental task (Y). Data description from result of the study is explained as follows. First, data description of achievement of student developmental task in terms of school type. According to objectives of the research that have been describe, stating that in this study disclosed the achievement of student developmental tasks that is in term by type of school, in the meaning that the type of school was intended by two categories, they are Senior High School and Islamic boarding school, which the data is described as below:

a. Data Description of Achievement of Senior High School Students' Developmental Task

Data result of the achievement of Senior High School students' developmental task described in Table 2 below:

Table 2. Frequency Distribution and Score Categories in Achievement of Senior High School Students' Developmental Task $(n=219)$

\begin{tabular}{|c|c|c|c|}
\hline Score Interval & Category & $\begin{array}{c}\text { Frequency } \\
(\mathrm{F})\end{array}$ & $(\%)$ \\
\hline $210-250$ & Very High $(\mathrm{VH})$ & 103 & 47,03 \\
\hline $169-209$ & $\operatorname{High}(\mathrm{H})$ & 111 & 50,68 \\
\hline $128-168$ & Medium (M) & 5 & 2,28 \\
\hline $87-127$ & Low (L) & 0 & 0 \\
\hline$\leq 86$ & Very Low (VL) & 0 & 0 \\
\hline \multicolumn{2}{|c|}{ Total } & 219 & 100 \\
\hline \multicolumn{4}{|c|}{ Average of Score Interval = 208,03 (High Category) } \\
\hline
\end{tabular}

Based on Table 2, it can be seen that the achievement of students' development tasks is in the Very High category with a total frequency of 103 or can be presented with a value of $47.03 \%$. Furthermore, in the High category its frequency is amounted 111 with a percentage value of $50.68 \%$, the Medium category its frequency is amounted 5 with a percentage value of $2.28 \%$, and the Low and Very Low category, their frequencies are amounted 0 of all students who are registered in Senior High School. From the data of 219 students are obtained a score interval average of 208.03 in High category.

b. Data Description of Achievement of Islamic Boarding School Students' Developmental Task

Data result of the achievement of Islamic Boarding School students' developmental task described in Table 3 below:

Table 3. Frequency Distribution and Score Categories in Achievement of Islamic Boarding School Students' Developmental Task $(\mathrm{n}=210)$

\begin{tabular}{|c|c|c|c|}
\hline Score Interval & Category & Frequency $(\mathrm{F})$ & $(\%)$ \\
\hline $210-250$ & Very High $(\mathrm{VH})$ & 77 & 36,67 \\
\hline $169-209$ & High $(\mathrm{H})$ & 122 & 58,10 \\
\hline $128-168$ & Medium $(\mathrm{M})$ & 11 & 5,24 \\
\hline
\end{tabular}




\begin{tabular}{|c|c|c|c|}
\hline Score Interval & Category & Frequency $(\mathrm{F})$ & $(\%)$ \\
\hline $87-127$ & Low (L) & 0 & 0 \\
\hline$\leq 86$ & Very Low (VL) & 0 & 0 \\
\hline \multicolumn{2}{|c|}{ Total } & 210 & 100 \\
\hline
\end{tabular}

Table 3 shows that the achievement of students' development tasks is in the Very High category with frequency of 77 or can be presented with a value of $36.67 \%$. Furthermore, the High category have frequency amounted 122 with a percentage value of $58.10 \%$, the Medium category have frequency amounted 11 with a percentage value of $5.24 \%$ and the Low and Very Low category have frequencies amounted 0 of all students who are registered in Islamic Boarding School. From the data of 210 students are obtained a score interval average of 201.39 in High category.

Second, the differences of achievement of student developmental tasks in terms of school type. Analysis of $t$-test data in level of achievement of students' development tasks in terms of school types that are namely Senior High School and Islamic Boarding School students are as follows in Table 4:

Table 4. Variant Analysis (t-test) Data of the Achievement of Senior High School and Islamic Boarding School Students' Developmental Task

\begin{tabular}{|c|c|c|c|c|c|c|c|c|}
\hline Variable & $\begin{array}{c}\text { Type of } \\
\text { School }\end{array}$ & N & Mean & Dk & MS & T & Sig. & Adj. \\
\hline \multirow{4}{*}{$\begin{array}{c}\text { Denior } \\
\text { High } \\
\text { Task } \\
\text { School }\end{array}$} & 219 & 208,03 & 1 & 6,641 & 3,665 &, 000 & Significant \\
\cline { 2 - 8 } & $\begin{array}{c}\text { Islamic } \\
\text { Boarding } \\
\text { School }\end{array}$ & 210 & 201,39 & & & & \\
\hline
\end{tabular}

According to data in Table 4 above, it can be seen that there are significant differences in the achievement of student development tasks based on type of school. Senior High School students have a higher level of developmental task than Islamic Boarding School students.

Student periodi is a form of transition period that passed by every individual from childhood to adult which starts from the range age of 12 years old or 13 years old and ends at the beginning of age 20s years old (Santrock, 2007). In this development period, there are many changes that are experienced by students, both biologically, cognitively and socially. Therefore, students are required to complete developmental tasks during the student's period to make their mental development will become mature when they start an adult life. One of the factors that influence an individual development is the environment. Hence, the achievement of developmental tasks will be different when it viewed in terms of school types or environment they interact (Ardi et al., 2012).

Based on the results of data analysis, it shows that the achievement of students' developmental tasks based on the type of school (students from Senior High School backgrounds and students from Islamic boarding school backgrounds) are in High category, 
this can also be seen from each sub-variable of students development task achievement in Senior high school and Islamic boarding school backgrounds that is in High category. From the results of data analysis, students who are from Senior high school backgrounds and students who are from Islamic boarding school backgrounds get highest average in the subvariables of politeness and attitude. The lowest average is found in the sub-variable of understanding of behavior to others, but even though the sub-variable of understanding of behavior to others can still be categorized as High.

The results of study described that the achievement of student development task in Senior high school background is higher when compared to students in Islamic boarding schools. The high score in Senior high school student occured because it is one of the formal educational institutions. The learning process combines both male and female students in a class. With this condition students can complete their developmental tasks naturally (Mahfuzh, 2007). Students who are not separated by gender have higher social relationship level than students who are separated. This theory applies to all indicators of student developmental tasks (Khairat, 2017). The smilar result of study that was also found by (Putra, 2017) in developing social relationships with friend in same gender and opposite, Senior high school students are in Very High category than students in Islamic Boarding School are in Medium category. Even though, the research samples are homogeneous and different from the types of samples in this study which are heterogeneous. But it still shows the same results.

There is the possible factor that influences the differences of achievement of student development task in Senior high school and Islamic boarding schools. It is school systematics. The kind of Senior high school students are generally not facilitated by the dormitary or living in the school environment with their friends and teachers, but students are free able to return to their homes after the school hours finished. Because of that, Senior high school students can directly interact with the society and get a lot of experiences and also can be educated by their parents directly. In comparison, relating to students in Islamic boarding schools student, they are required to live in a dormitory with the roomates and caregiver teachers who also live in a dormitory (Samong et al., 2016). The student experiences interacting in Islamic boarding schools can be said to be minimal, because the society that are met at school and outside of school are the same person and also human characteristics that they encountered are also have similar characters. So, students in Islamic boarding schools have less challenge in social interacting, because there is a lack of reference to human characteristics encountered. Further, boarding school that is in one location and within a very close distance contributes a lot in creating saturation of children in boarding schools.

The findings of study (Sagita et al., 2013) showed that students adaptation in schools while in researching were quite good at $35.87 \%$. In this case, students are able to show and they can adapt with things in school such as self-adaptation with fellow students, with the teacher and the rules that exist in the school. At least, students can feel comfortable and calm to do learning activities at school.

Afterwards, according to (Sofyan, 2005) adjustment is a personal ability to live and getting along naturally with their environment, so they can feel satisfied with theirselves and their environment. Thus, it seen clearly the role and position of adjustment in individuals' live, including in students' live in the school environment. The form of student adjustment in school is a demand to students able to adjust to the teacher, friends and school environment. 
Another factor that has been identified and became one of causes from the differences of the development task achievement of Senior high school students and boarding school students is the pattern of parenting. Senior high school students are only taken care of by their inner families with a pattern of parenting that not diverse, which makes it easy for Senior high school students when returning home easily to follow and adapt. However, it is different from Islamic boarding school students, who get diverse parenting. Talking about parenting varies from the very disciplined to being very soft. Both have the negative effects (Hendriyenti, 2014).

Reffering to results of research from (Ridho Ilahi et al., 2013) stated that the dominant factor affecting violations of student discipline is the psychological condition of the students themselves. The external factors that influence violations of student discipline are the school environment, family environment and society environment.

In the indicator of student development task, social maturity is able to develop social relations with friends who have same gender and different gender. The level of achievement of student developmental task in Islamic boarding school is lower than student in Senior high schools. The achievement of student developmental task is influenced by social support (Maslihah, 2011). The rules for not interacting with friends of opposite gender make it difficult for students at Islamic boarding schools to achieve developmental tasks, one of which is in developing relationships with others. The case phenomenon shows that there are rules which established by Islamic boarding schools. This case is thought to inhibit social interaction between students with opposite gender. These conditions and situations causes students being unable to fulfill their developmental tasks, further the rules that bind all students of boarding school and limit the space for finding their identity (Putra, 2017).

\section{Conclusion}

According to data and findings that obtained in this study, statistical analysis and hypothesis testing have been reviewed and elaborated in the discussion, it can be concluded that there are differences in the achievement of student developmental task in Senior high school and Islamic boarding schools. In other hands, the development tatsk achievement of Senior high school students is higher than Islamic boarding school students.Hereafter, the things that affected these results are differences in student interaction times. Senior high school students have more time to interact with others than Islamic boarding school students. The case phenomenon shows that there are regulations which established by Islamic boarding schools. This case is thought to inhibit social interaction between students with opposite gender. These conditions and situations causes students being unable to fulfill their developmental tasks, further the rules that bind all students of boarding school and limit the space for finding their identity (Putra, 2017).

Furthermore, the factors that influence the difference of the development task achievement of Senior high school students and Islamic boarding schools are self-adjustment (Pritaningrum, 2013). In case, students who study in Islamic boarding schools will experience shoot culture with a new environment by sharing the rules that are applied. It is different from the previous student schools.Making student success or failure in self adjustments is influenced by two factors. They are the factors from within self (internal) and factors from outside (external). First, the internal factors such as physical condition, heredity, and maturity (for example: emotional, intellectual, and social). Second, the external factors 
are included social support and cultural. So, in the early years of students in Islamic boarding schools are preoccupied students to adapt theirselves with new environment.

Finally, the environment greatly influences students in achieving developmental tasks in advance (Lestari, Hidayah, \& Murti, S, 2006). In last, there is a difference of the developmental task achievement of students who study in Senior high school with students who are in Islamic boarding schools, and also it accordance with the results of this study.

\section{References}

Ardi, Z., Ibrahim, Y., \& Said, A. (2012). Capaian Tugas Perkembangan Sosial Siswa dengan Kelompok Teman Sebaya dan Implikasinya Terhadap Program Pelayanan Bimbingan dan Konseling. Konselor, 1(1).

Fiana, F. J., Daharnis, D., \& Ridha, M. (2013). Disiplin Siswa di Sekolah dan Implikasinya dalam Pelayanan Bimbingan dan Konseling. Konselor, 2(3), 26-33. https://doi.org/10.24036/02013231733-0-00

Hendriyenti. (2014). Pelaksanaan program Boarding School Dalam Pembinaan Moral Siswa di SMA Taruna Indonesia Palembang. Ta'dib, XIX(02), 203-226.

Hurlock, E. B. (1980). Psikologi Perkembangan. Alih Bahasa: Meitasari Tjandrasa. Erlangga.

Khairat, P. R. \& I. (2017). Perbedaan Kematangan Sosial Siswa yang Berasal dari Sekolah Homogen dan Sekolah Heterogen. Jurnal Kajian Bimbingan Dan Konseling, 2(8), 148-156.

Lestari;, E. D., Hidayah, D., \& Murti, S, K. (2006). Paediatrica Indonesiana. 46(7), 174-178. https://doi.org/10.14238/pi

Mahfuzh, J. (2007). Psikologi Anak dan Siswa Muslim. Al-Kautsar Library.

Maslihah, S. (2011). Studi Tentang Hubungan Dukungan Sosial, Penyesuaian Sosial Di Lingkungan Sekolah Dan Prestasi Akademik Siswa Smpit Assyfa Boarding School Subang Jawa Barat. Jurnal Psikologi Undip, 10(2), 103-114. https://doi.org/10.14710/jpu.10.2.103-114

Prayitno. (1997). Seri Pemandu Pelaksanaan Layanan Bimbingan dan Konseling di Sekolah Menengah Pertama. Padang State University.

Pritaningrum, M. (2013). Penyesuaian Diri Siswa yang Tinggal di Pondok Pesantren Modern Nurul Izzah Gresik Pada Tahun Pertama. Jurnal Psikologi Kepribadian Dan Sosial, 02(03).

Putra, F. (2017). Ketercapaian Tugas-Tugas Perkembangan Siswa SMA Dan Siswa Pondok Pesantren . Counseling Care, 1(1), 27-34.

Rahmawati, A. D. (2015). Kepatuhan Santri Terhadap Aturan di Pondok Pesantren Modern. Program Magister Psikologi Sekolah Pascasarjana UMS.

Riadi, A. (2016). Pendidikan Karakter Di Madrasah/Sekolah. Ittihad, 14(26), 1-10. https://doi.org/10.18592/ittihad.v14i26.868

Ridho Ilahi, Syahniar, \& Ibrahim, I. (2013). Faktor yang mempengaruhi pelanggaran disiplin siswa. 2(1), 20-25.

Sagita, Erlamsyah, \& Syahniar. (2013). Hubungan Antara Perlakuan Orangtua Dengan 
Penyesuaian Diri Siswa Di Sekolah. Ilmiah Konseling, 1(3), 1-10.

Samong, F., Suryadi, A., \& Budimansyah, D. (2016). The Development of Character Education in Primary Schools through the Enhancement of School Culture. 77-79. https://doi.org/10.2991/icse-15.2016.17

Santrock, J. W. (2007). Remaja. Gelora Aksara Pratama.

Sofyan, S. (2005). Remaja dan Permasalahannya. Bandung:Alfabeta.

Wirawan, S. (2012). Psikologi Remaja. Jakarta: Raja Grafindo Persada. 